\title{
ARTICLE
}

\section{PROPERTY OF UPGRADED SOLID AND LIQUID PRODUCTS OBTAINED FROM BAGANUUR LIGNITE BY THERMAL REACTION WITH SOLVENT}

\author{
Ariunaa A. *, Otgonchuluun D., Purevsuren B. and Davaajav Ya. \\ Laboratory of Coal Chemistry and Technology, Institute of Chemistry and Chemical Technology, \\ Mongolian Academy of Sciences, Ulaanbaatar, Mongolia
}

ARTICLE INFO: Received: 26 Mar, 2018; Accepted: 21 Dec, 2018

\begin{abstract}
The coal of Baganuur deposit have been investigated to determine its technical characteristics, elemental and petrographical maceral compositions. On the basis of proximate, ultimate, petrographic and FTIR analysis, the obtained results have confirmed that the Baganuur coal is a low rank lignite B2 mark. The liquid tar, produced through thermolysis of Baganuur coal, was investigated by FTIR, ${ }^{13} \mathrm{C}$ and ${ }^{1} \mathrm{H} N M R$ spectrometric analysis. The results of thermolysis of Baganuur coal in tetralin has a constant mass ratio between coal and tetralin $(1: 1.8)$ at $450^{\circ} \mathrm{C}$, which shows that $40.0 \%$ of liquid product can be obtained after thermal decomposition of the coal organic mass.
\end{abstract}

Keywords: low rank coal, petrographic analysis, pyrolysis, thermolysis;

\section{INTRODUCTION}

Two step direct coal liquefaction processes involve the consecutive liquefaction of coal and upgrading (by hydrocracking) of the liquefied products. Experiments show that a major part $(>80 \mathrm{wt} \%)$ of most low and medium rank bituminous coals can be dissolved in a suitable solvent (such as tetralin) within several minutes at an elevated temperature (e.g. $\left.450^{\circ} \mathrm{C}\right)$ [1-6]. However, much longer reaction time and severe reaction conditions are required in the hydrocracking process, where conversion depends on the structures and reactivity of the primary coal extract.

Effective utilization process of low rank coal has not yet been established due to the high moisture level, low heating value, spontaneous ignition behaviour and greater generation of carbon dioxide through direct combustion [7]. Generation of carbon dioxide by direct combustion of coal, especially low rank coal, has become a serious problem in terms of global warming, and processes for the production of clean solid fuel are currently receiving priority attention, thus making it imperative for the adoption of new and advanced technologies for their utilization. Typical industrial utilization processes include direct combustion of pulverized coal for power 
generation, gasification of coal for synthesis gas or fuel gas production, and carbonization for steel production [8]. In addition, liquefaction is one of the challenging technologies in the comprehensive utilization of coal [9]. Upgrading process can be considered as a kind of possible solution to utilizing low rank Mongolian coal. This process can reduce moisture and increase the thermal value of coal and prevent self-heating and spontaneous combustion during transportation and storage [10].

Mongolia is a country with rich coal resources. Coal has been believed to be the major energy source among fossil fuels in the coming century because of the ease of its availability. Total geological resources of coal are estimated at 173 billion tonnes and the proven coal reserve is 9.3 billion tonnes. In 2010, Mongolian coal production increased to 23 million tonnes, from which 17 million tonnes were exported to China. Coal, with its property, is mostly lignite, sub-bituminous and bituminous.

Coal reserves chiefly occur in a large brown coal basin (Jurassic origin) located in

\section{MATERIALS AND METHODS}

A sample coal, approximately $50 \mathrm{~kg}$, was taken by hand picking different size coal pieces from a newly opened coal seam for local commercial consumption at local demand.

Sample preparation, proximate and ultimate analysis of coal from the Baganuur deposit were performed according to Mongolian National Standards MNS 656-79 (moisture content), MNS 652-79 (ash yield), MNS 65479 (volatile matter yield), MNS 669-87 (gross calorific value) and MNS 895-79 (sulphur content).

Petrographic analysis was performed on polished particulate mounts, according to recommendations by the International Committee for Coal and Organic Petrology (ICCP) [12]. Vitrinite reflectance was measured using an Axio Imager M2m the central economic region of Mongolia, which has the Baganuur, Ovdogkhudag, Aduunchuluun, Tevshiin Govi, Khoot, Tsaidam Nuur and Shivee Ovoo deposits [11].

The conversion of coal into oil and gas is critically important for the country, which will have an impact on national security and sustainable economic development. Therefore, a much more comprehensive investigation into the afore-mentioned major coal deposits by using modern instrumental analysis, such as petrographic and different pyrolytic experimental methods, is critical for the future development of Mongolia's coal processing industry. Proceeding from this premise, the coal from Baganuur deposit has been chosen for a much more detailed investigation on thermal processing, including pyrolysis and thermolysis, characterization of obtained solid (hard residue) and liquid products.

The sample used in this study is lignite from Baganuur in Mongolia. The Baganuur deposit is located $130 \mathrm{~km}$ east of Ulaanbaatar, on the territory of Bayandelger soum of Tov aimag (province) and coal has been mined here since 1978.

microscope (Zeiss, Germany) and Fossil software (Hilgers, Germany) on 50 individual vitrinite macerals in random mode. In addition, fluorescence microscopy was used for rapid qualitative information on maturity and organofacies. Resedimented vitrinite particles are characterized by higher reflectivity than autochthonous vitrinite. Usually, only the vitrinite population with the lowest reflectance value is measured and reported. Maceral group analysis was performed using the same microscope and software by point counting of 500 individual macerals.

The pyrolysis experiments of coal samples were performed in a laboratory vertical cylindrical stainless retort with a capacity of containing $1000 \mathrm{~g}$. of the sample. The retort was placed in an electric furnace (model 
SNOL) with a maximum temperature of $950^{\circ} \mathrm{C}$. A chrome-alumel thermocouple and an equipment for temperature control (potentiometer) were immersed in the coal bed to measure the actual heating temperature. The retort was connected with an air-cooled iron tube and water-cooled laboratory glass condenser and a collection vessel for the condensate of liquid product (pitch and pyrolysis water). The non-condensable gases after the water-cooled condenser were left the system through a thin glass tube. The experiments were carried out at a temperature of $500-600^{\circ} \mathrm{C}$ and the heating rate was $20^{\circ} \mathrm{Cmin}^{1}$. The yields of products, including solid residue (coal char), tar and pyrolysis water, were determined by weighing, and the yield of gases by their difference.

The thermolysis of coal samples was carried out in a stainless steel autoclave using tetralin as a hydrogen donor solvent. Prior to the treatment, coal samples were air dried for 24 hours, powdered to a particle size $<0.2 \mathrm{~mm}$, following which $1 \mathrm{~g}$ coal sample was mixed with $1.8 \mathrm{~g}$ tetralin (mass ratio 1:1.8), sealed in the autoclave and heated in a laboratory furnace for 2 hours to temperatures of $350^{\circ} \mathrm{C}, 400^{\circ} \mathrm{C}$, and $450^{\circ} \mathrm{C}$ respectively. After completion of each experiment, the autoclave was cooled to room temperature, and all uncondensed gas and resulting liquid products were removed, filtered, and the solid residue from the filter was subjected to sequential extraction with chloroform in a Soxhlet apparatus. An extract of liquid products of thermal dissolution of coal in tetralin was distilled by a laboratory rotary evaporation apparatus for completely removing chloroform. The degree of coal conversion was determined by the loss of the coal organic matter (COM) after extraction and also change in the ash contents of the initial coal samples and insoluble residue. The yields of pyrolysis products, including solid residue (coal char), tar (condensed liquid product) and pyrolysis water were determined by weighing, and the yield of gases was calculated by their difference.The percentage yield of pyrolytic oil, char and non-condensable volatiles were calculated on the basis of feed (Eqs. (1)-(3)).

$$
\begin{aligned}
& \% \text { Liquid yield }=(\text { Liquid weight } / \text { Feed weight }) * 100 \\
& \% \text { Char yield }=(\text { Char weight } / \text { Feed weight }) * 100 \\
& \% \text { Gas yield }=100-(\% \text { Liquid yield }+\% \text { Char yield })
\end{aligned}
$$

The FTIR spectra of the samples were obtained on an Interspec 200-X series of FTIR spectrometers with PIKE Diffusion IR accessories using a $\mathrm{KBr}$ disc containing $1 \%$ finely ground samples. All the spectra were measured in the frequency range of 4000 to $400 \mathrm{l} / \mathrm{cm}$, and 32 scans were taken per sample.
${ }^{1} \mathrm{H}-\mathrm{NMR}$ and ${ }^{13} \mathrm{C}-\mathrm{NMR}$ spectra were obtained with a BRUKER AVIII $600 \mathrm{MHz}$ spectrometer. The tar samples $(20 \mathrm{mg}$ for ${ }^{1} \mathrm{H}, 80 \mathrm{mg}$ for ${ }^{13} \mathrm{C}$ ) were in dissolved in deuterochloroform $\left(\mathrm{CDCl}_{3}\right)$, which was used as an internal standard. Chemical shifts are reported in $\mathrm{ppm}(\delta)$. 


\section{RESULTS AND DISCUSSION}

The results of ultimate, proximate and from Baganuur deposit are shown in Table 1. organic petrographic analysis of coal samples

Table 1. Proximate and Ultimate analysis of Baganuur coal

\begin{tabular}{|c|c|c|c|c|c|c|c|c|c|}
\hline $\begin{array}{c}\text { Name } \\
\text { of coal } \\
\text { deposit }\end{array}$ & $\begin{array}{c}\text { Mois- } \\
\text { ture, } \\
W^{u}, \%\end{array}$ & $\begin{array}{l}\text { As } h, \\
A^{d}, \%\end{array}$ & $\begin{array}{c}\text { Yield of } \\
\text { volatile } \\
\text { matter, } \\
V^{\text {daf } \%}\end{array}$ & $\begin{array}{c}\text { Sulphur } \\
S_{t}^{\text {do }}\end{array}$ & $\begin{array}{c}\text { Calorific } \\
\text { value, } \\
Q^{\text {daf }} \kappa c a l \\
\kappa g\end{array}$ & $\begin{array}{c}\text { Car- } \\
\text { bon, } \\
C^{\text {dafo }} \%\end{array}$ & $\begin{array}{c}\text { Hydro- } \\
\text { gen, } \\
H^{\text {dafo }}\end{array}$ & $\begin{array}{c}\text { Nitro- } \\
\text { gen N } \\
\%\end{array}$ & $\begin{array}{c}\text { Oxygen } \\
O^{\text {daf } \%}\end{array}$ \\
\hline Baganuur & 9.4 & 13.3 & 47.0 & 0.56 & 5712 & 64.2 & 5.74 & 0.26 & 29.8 \\
\hline
\end{tabular}

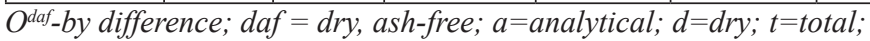

Results of proximate and ultimate analysis indicate that coal from Baganuur deposit is a low rank A (ISO 11760) coal which is vitrinite-rich, and has low ash and sulphur content. According to the ASTM D-388 classification, it is of lignite rank. The volatile matter and carbon contents of Baganuur coal was $\mathrm{V}^{\mathrm{daf}}=47.0 \%$ and $\mathrm{C}^{\mathrm{daf}}=64.2 \%$ respectively, which show that the coal belongs to the class of B2 mark according to Russian genetic technological classification (GOST 25543-82).

The FTIR spectra of Baganuur lignite and char were recorded. A typical IR spectrum is shown in Figure 1.

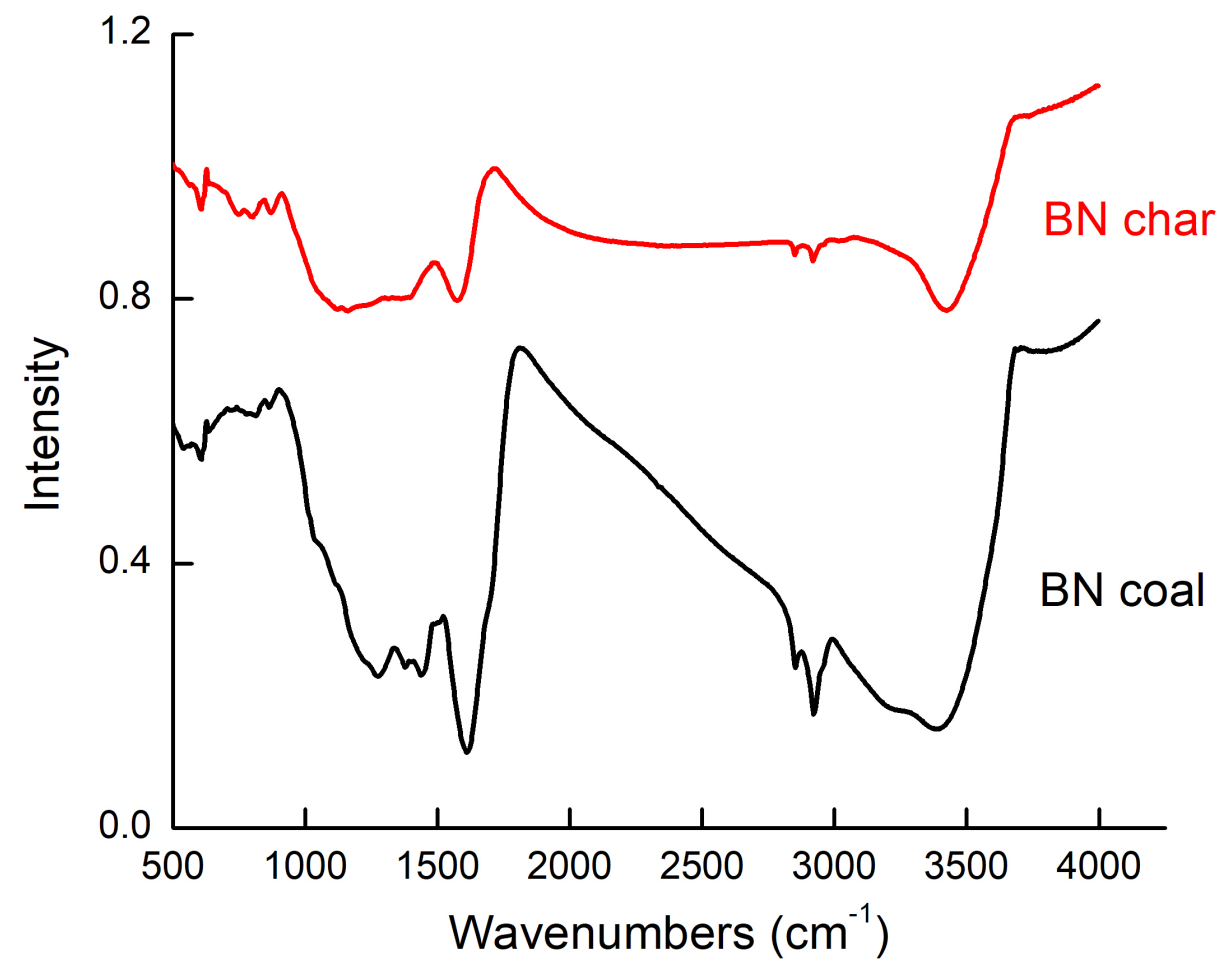

Figure 1. The FTIR spectra of Baganuur lignite and char 
Fig. 1 shows the FTIR spectrogram of the Baganuur coal and char. The FTIR characteristic peaks were investigated, mainly including: $3385 \mathrm{~cm}^{-1}$ (hydroxyl), $2993 \mathrm{~cm}^{-1}$ (aliphatic C-H stretching), 2925, 1446 and $1401 \mathrm{~cm}^{-1}$ (asymmetric stretching vibration of aliphatic methylene group C-H structure), 2852 and $1387-1332 \mathrm{~cm}^{-1}$ (symmetric vibration of aliphatic methyl group $\mathrm{C}-\mathrm{H}), 1808 \mathrm{~cm}^{-1}$ and $1606-1518 \mathrm{~cm}^{-1}$ (aliphatic $\mathrm{C}=\mathrm{O}$ groups) and (aromatic $\mathrm{C}=\mathrm{C}$, aromatic ring stretch), $1277 \mathrm{~cm}^{-1}$ (vibration of aromatic C-O), 906$752 \mathrm{~cm}^{-1}$ (vibrations of aromatic rings). It can be seen from Fig. 1 that the char has a functional structure similar to that of raw coal but with varying peak absorption intensities. The infrared absorption intensity at $1704 \mathrm{~cm}^{-1}$ weakens after pyrolysis, indicating the decrease of carbonyl and carbonyl groups, which may be attributed to the destruction and reduction of oxygen-containing functional groups.
The intensity of aliphatic hydrocarbon peaks (including the vibration of aliphatic methylene and methyl group C-H) drops significantly after pyrolysis. This reduction coincides with the fracture of aliphatic side chains to form methane or other organic gases. The absorption intensity of hydroxyl at $3600-3200 \mathrm{~cm}^{-1}$ gradually reduces at the pyrolysis temperature of $600^{\circ} \mathrm{C}$, mainly due to the reduction of various hydroxyl groups and sample water. After pyrolysis, the absorption peak narrows and centralizes to $3420 \mathrm{~cm}^{-1}$, which is attributed to the decreasing hydroxyl type.

Petrographic analysis has been carried out on polished coal samples using the same microscope and software by point counting of 500 individual macerals. The white-black and coloured petrographic photographs are presented in Figure 2 and the maceral group (vitrinite, inertinite and liptinite) composition is given in Table 2.

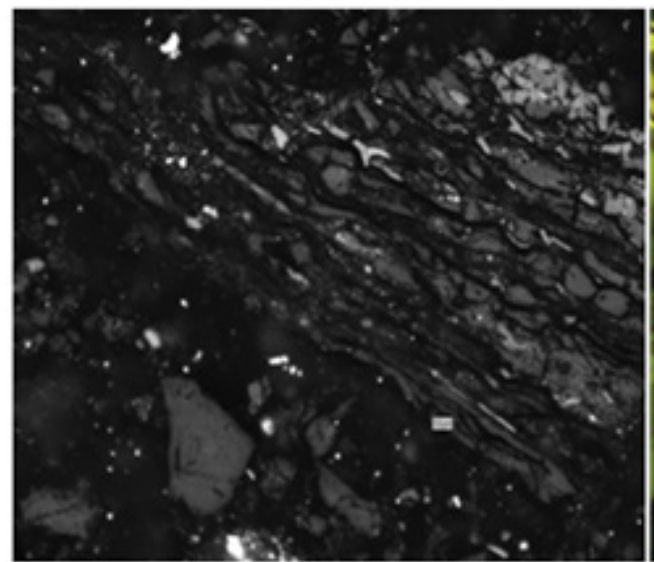

A

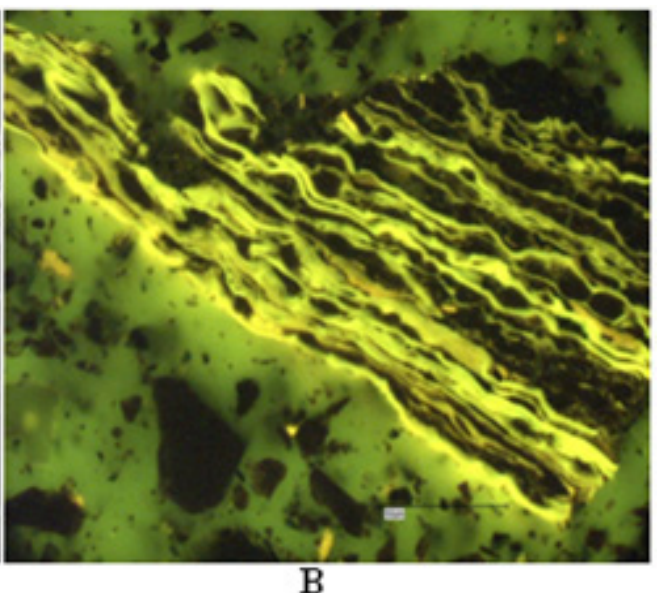

B

Figure 2. The black-white (A) and coloured (B) petrographic photographs of polished coal sample of Baganuur deposit

The vitrinites fragments are grey coloured with varying sizes and the inertinites are white coloured stripes in the white-black photograph Figure 2A. But the liptinites are not observed in the black-white photograph Figure 2A and they are yellow coloured stripes in colour photograph Figure 2B. The vitrinite fragments are black coloured in coloured photograph Figure 2B. The polymeric (epoxide) binder has a black coloured background in the blackwhite photograph Figure 2A and a green coloured background in coloured photograph Figure 2B.The minerals in the polished coal sample are observed as a brilliant pieces in the microscope, but they are absent in blackwhite (A) and coloured (B) petrographic photographs[13]. 
Table 2. Petrographic analysis results of Baganuur coal

\begin{tabular}{|c|c|c|c|c|}
\hline Name of coal deposit & Vitrinite, $\%$ & Liptinite, $\%$ & Inertinite, $\%$ & Minerals, $\%$ \\
\hline Baganuur & 75 & 9 & 4 & 12 \\
\hline
\end{tabular}

The maceral group composition in Table 2 shows that the organic matter of Baganuur coal is characterized with a highest content of vitrinite and low contents of inertinite, liptinite and minerals connected with coal organic mass. The degree of vitrinite reflectance $\left(\mathrm{RV}^{\mathrm{t}}=0.35 \%\right)$ was measured using an Axio Imager M2m microscope and Fossil software on 50 individual vitrinite macerals in random mode. This value $0.35 \%$ is characteristic for a low rank lignite and class of B2 mark by Russian classification [14]. Therefore, the results of determined technical characteristics, elemental and maceral group composition, degree of vitrinite reflectance show that Baganuur coal is a low rank B2 mark lignite, which is suitable for thermal processing such as pyrolysis and thermolysis.

The Baganuur coal was pyrolized in a bigger scale retort at $500-600^{\circ} \mathrm{C}$ to determine the yield of pyrolysis products, including hard residue, tar, pyrolytic water and gas were determined as illustrated in Table 3.

Table 3.The results of pyrolysis experiments of Baganuur coal

\begin{tabular}{|c|c|c|c|c|c|}
\hline $\begin{array}{c}\text { Name of coal } \\
\text { deposit }\end{array}$ & Temperature ${ }^{\circ} \mathrm{C}$ & Hard residue, \% & Tar, \% & Pyrolytic water, \% & Gas and loss, \% \\
\hline \multirow{2}{*}{ Baganuur } & $500-600$ & 60.3 & 6.9 & 14.9 & 17.9 \\
\cline { 2 - 6 } & 56.8 & 7.0 & 14.8 & 21.4 \\
\hline \multicolumn{2}{|c|}{ Average } & 58.6 & 7.0 & 14.9 & 19.5 \\
\hline
\end{tabular}

Data in Table 3 show that $58.6 \%$ of the organic mass of Baganuur coal remained as a hard residue after pyrolysis. The yield of all liquid and gas products is $41.4 \%$, which proves that there was an intensive thermal decomposition of the coal organic mass with a higher degree of conversion.

As it is known, organic mass of lignite and sub-bituminous coal are characterized with lower thermal stability and therefore, they are more suitable for gasification and liquefaction [15].

Also, thermolysis experiments of Baganuur coal in the medium tetralin (hydrogen donor solvent) have been carried out in a laboratory scale autoclave at $350-450^{\circ} \mathrm{C}$ and the yield of thermolysis products, including hard residue, tar and gas were determined as illustrated in Table 4.

Table 4. The results of thermolysis experiments of Baganuur coal

\begin{tabular}{|c|c|c|c|c|c|c|}
\hline $\begin{array}{c}\text { Name of coal } \\
\text { deposit }\end{array}$ & $\begin{array}{c}\text { Donor- } \\
\text { Solvent, } g\end{array}$ & $\begin{array}{c}\text { Coal: } \\
\text { solvent }\end{array}$ & $\begin{array}{c}\text { Temperature, } \\
{ }^{\circ} \mathrm{C}\end{array}$ & $\begin{array}{c}\text { Hard residue, } \\
\%\end{array}$ & Tar, \% & $\begin{array}{c}\text { Gas and loss, } \\
\%\end{array}$ \\
\hline \multirow{3}{*}{ Baganuur } & \multirow{3}{*}{ Tetralin } & \multirow{2}{*}{$1: 1.8$} & 350 & 70.5 & 14.3 & 15.2 \\
\cline { 4 - 7 } & & 400 & 45.5 & 31.8 & 22.7 \\
\cline { 4 - 7 } & & 450 & 35 & 40 & 25 \\
\hline
\end{tabular}

Data in Table 4 show that the yield of hard residue decreases intensively and the yield of thermolysis products (tar and gas) increases intensively as the heating temperature is raised. The highest yield (40\%) of tar and gas is obtained by using mass ratio of coal and tetralin at $1: 1.8$ at $450^{\circ} \mathrm{C}$. At this stage, $35 \%$ of the organic mass of Baganuur coal remained as a hard residue after thermolysis. The yield all liquid and gas products is $65 \%$, which evidences that there was also an intensive thermolysis of the coal organic mass with 
higher degree of conversion, almost 1.6 times higher than that of pyrolysis.

Hard thermolysis obtained as a result of determined technical characteristics of initial coal sample are given in Table 5 .

Table 5. Characteristics of solid product of pyrolysis and thermolysis of Baganuur coal

\begin{tabular}{|c|c|c|c|c|}
\hline \multirow{2}{*}{\multicolumn{2}{|c|}{ Name of coal deposit }} & \multirow{2}{*}{$\begin{array}{l}\text { Moisture, } \\
W^{a}, \% A^{d}\end{array}$} & Ash,\% & Volatile matter,\% \\
\hline & & & $V^{d a f}$ & \\
\hline \multirow{3}{*}{$\begin{array}{c}1 \\
\infty \\
\infty \\
\infty\end{array}$} & Initial coal sample & 9.4 & 13.3 & 47.0 \\
\hline & Hard residue after pyrolysis & 2.8 & 13.9 & 8.3 \\
\hline & Hard residue after thermolysis $\left(450^{\circ} \mathrm{C}\right)$ & 3.7 & 29.6 & 17.4 \\
\hline
\end{tabular}

Data in Table 5 show that the yield of volatile matter of pyrolysis and thermolysis hard residues decreased 3.6 times compared to that of initial coal sample. This is also an indication of the intensive thermolysis that coal organic mass undergoes.

FTIR, ${ }^{13} \mathrm{C}$ and ${ }^{1} \mathrm{H}$ NMR analysis have been carried out for the characterization of liquid product after thermolysis and the spectrums are shown in Figures 3-5.

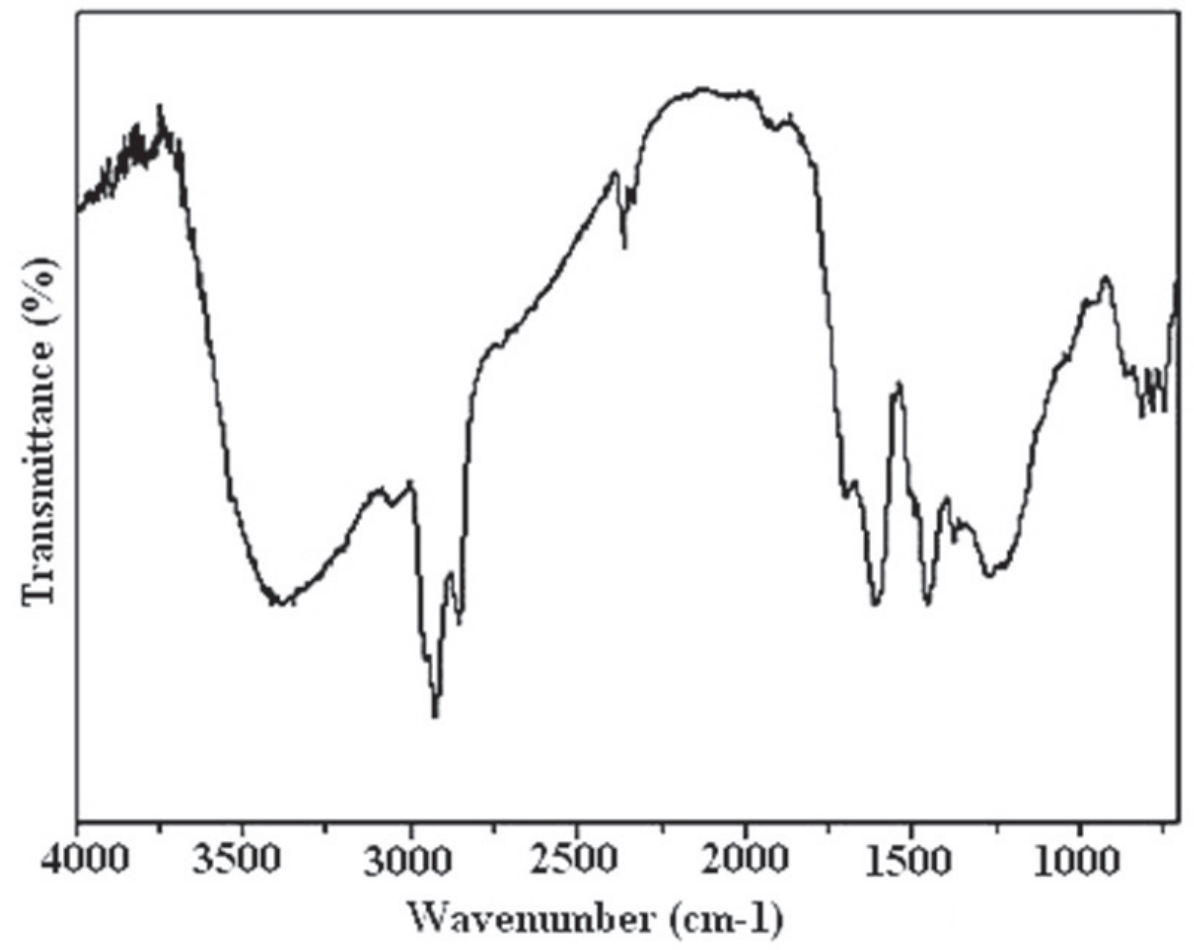

Figure 3. FTIR spectra of liquid tar product after thermolysis

In the FTIR spectra of tar product after thermolysis in the presence of tetralin there were observed strong absorption, mainly including $\quad 3600-3200 \mathrm{~cm}^{-1} \quad$ (hydroxyl), $3000 \mathrm{~cm}^{-1}$ (aromatic C-H stretching), 2900 and
$1408 \mathrm{~cm}^{-1}$ (asymmetric stretching vibration of aliphatic methylene group $\mathrm{C}-\mathrm{H}$ structure), 2805 and $1370 \mathrm{~cm}^{-1}$ (symmetric vibration of aliphatic methyl group C-H), $1600-1518 \mathrm{~cm}^{-1}$ (aromatic $\mathrm{C}=\mathrm{C}$, aromatic ring stretch), 
$1277 \mathrm{~cm}^{-1}$ (vibration of aromatic C-O), and $906-752 \mathrm{~cm}^{-1}$ (vibrations of aromatic rings). Therefore, tar product of Baganuur coal after thermolysis mainly consist of aliphatic, aromatic, and heterocyclic organics and aromatic-aliphatic hydrocarbons. It is known that some unstable oxygen-containing functional groups decompose to generate large amounts of polar compounds.

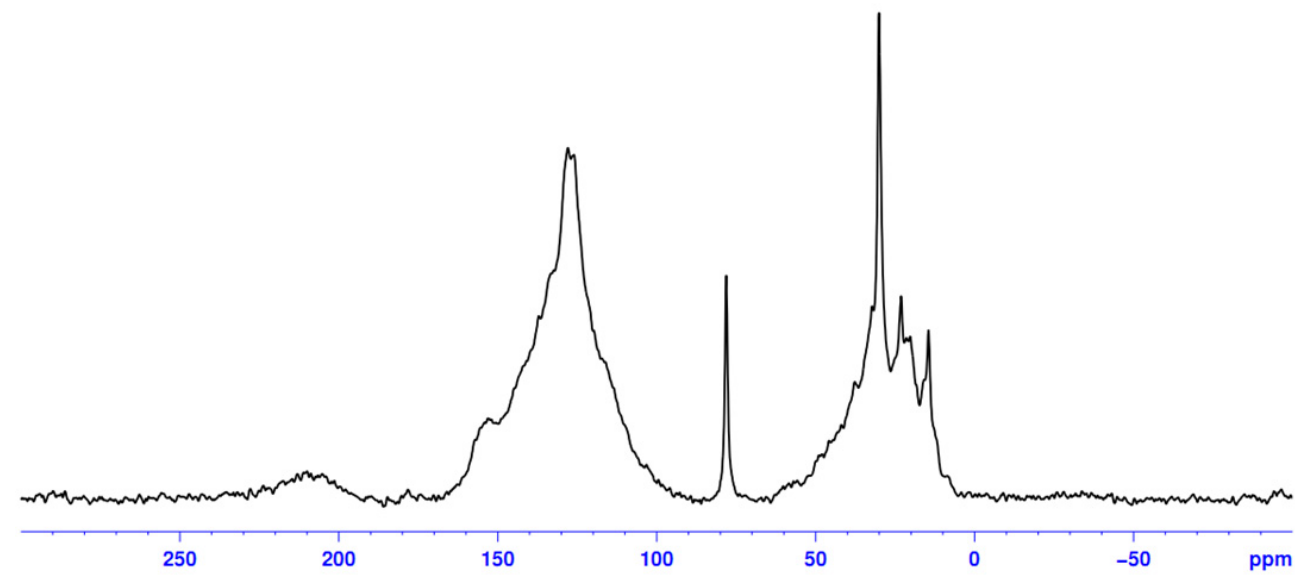

Figure 4. ${ }^{13} \mathrm{C}$ NMR spectra of liquid tar product after thermolysis

Aromatic $\mathrm{C}$ at $110-120 \mathrm{ppm}$; aliphatic $\mathrm{C}$ were observed in the ${ }^{13} \mathrm{C}$ NMR spectra of of $-\mathrm{CH},-\mathrm{CH}_{2}$ and $-\mathrm{CH}_{3}$ groups at $60-70 \mathrm{ppm}$ liquid tar product after thermolysis.

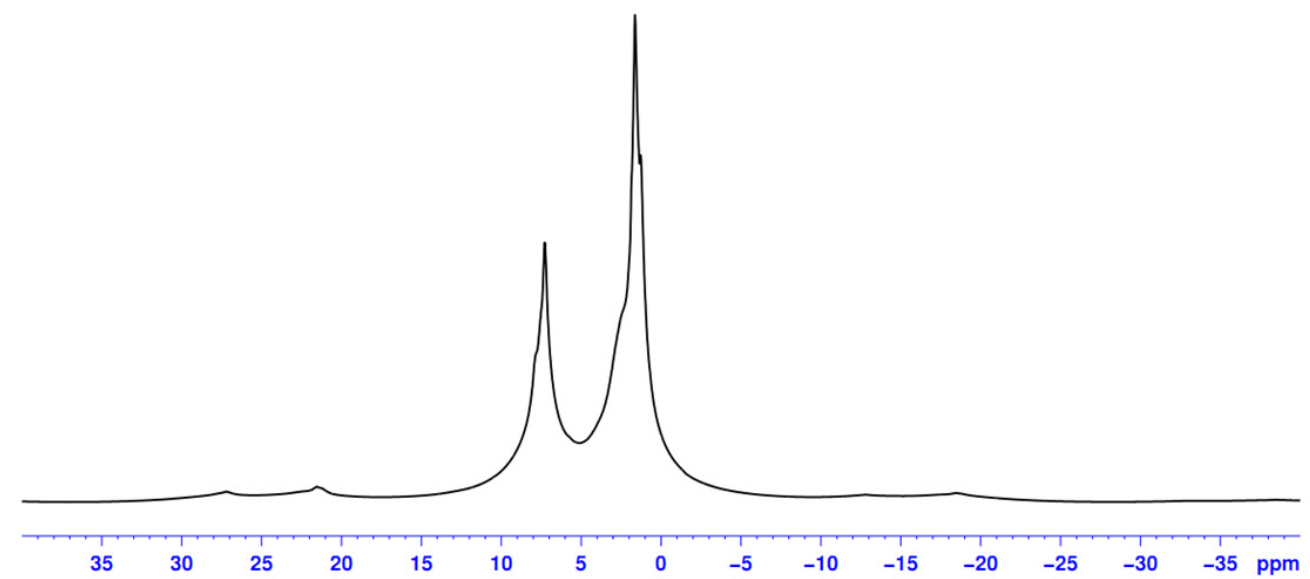

Figure 5. The ${ }^{1} H$ NMR spectra of liquid tar product after thermolysis

Strong absorption bands for $\mathrm{H}$ of aromatic - $\mathrm{CH}$ group at $7 \mathrm{ppm}$ and for $\mathrm{H}$ of aliphatic $-\mathrm{CH}_{3},-\mathrm{CH}_{2}$ and $-\mathrm{CH}$ groups at $1-3$ ppm were observed in the ${ }^{1} \mathrm{H}$ NMR spectra of liquid tar product after thermolysis in the presence of tetralin. The ${ }^{13} \mathrm{C}$ and ${ }^{1} \mathrm{H}$ NMR spectra of liquid tar product show that the tar of Baganuur coal after thermolysis also consists mainly of aliphatic, aromatic and aromatic-aliphatic hydrocarbons. 


\section{CONCLUSIONS}

On the basis of proximate, ultimate, petrographic and FTIR analysis, it has been confirmed that the Baganuur coal is a low rank B2 mark lignite and it is suitable for thermal processing including pyrolysis and thermolysis.

The results of pyrolysis experiment of Baganuur coal show that $58.6 \%$ of coal organic mass remained as a hard residue after pyrolysis. The yield of all liquid and gas products is $41.4 \%$ which is an evidence that there was intensive thermal decomposition of the coal organic mass with a higher degree of conversion.

The results of thermolysis of Baganuur coal in tetralin with a constant mass ratio between coal and tetralin $(1: 1.8)$ at $450^{\circ} \mathrm{C}$ show that $40.0 \%$ of liquid product can be obtained after thermal decomposition of the coal organic mass.

The FTIR, ${ }^{13} \mathrm{C}$ and ${ }^{1} \mathrm{H}$ NMR spectra show that the tar product of Baganuur coal, after thermolysis, consists mainly of aliphatic, aromatic and aromatic-aliphatic hydrocarbons.

\section{REFERENCES}

[1] Neavel, R.C., Fuel, 55, 1976, p. 237.

[2] Neavel, R.C., In Coal Science, Vol. 1 (Eds M. L. Gorbaty, J. M. Larsen and I. Wender), Academic Press, New York, 1981, p. 1.

[3] Gibbins, J. R. And Kandiyoti, R., Fuel Process. Technol. 24, 1990, p. 237.

[4] Gaines, A. F., Li, C-Z., Bartle, K. D., Madrali, E. S. and Kandiyoti, R., In Proceeding of the 1991 International Conference on Coal Science, Butterworth-Heineman, Oxford, 1991, p. 830.

[5] Li, C.-Z., Madrali, E.S., Wu, F., Xu, B., Cai, H.-Y., Guell, A.J. and Kandiyoti, R. Fuel, 73, 1994, p. 851.

[6] Moroni, E.C., Am. Chem. Soc. Div. Fuel Chem. Preprints, 36, 1991, p. 433.

[7] Yoshiki Sato, Satoshi Kushiyama, Yasuhiko Kondo, Hideyuki Takagi, Katsuhisa Maruyama, and Noriko Yoshizawa, Property of upgraded solid product from low rank coal by thermal reaction with solvent. Fuel Process. Technol, 88, 2007, pp. 333-341.

[8] W. C. Xu, K. Matsuoka, H. Akiho, M. Kumagai, and A.Tomita, Fuel 82, 2003, p. 677

[9] H. Hu, J. Bai, S. Guo, and G. Chen, Fuel, 81, 2002, p. 1521.

[10] B. Avid, Y. Sato, K. Maruyama, Y. Yamada, B. Purevsuren. Effective utilization of Mongolian coal by upgrading in a solvent. Fuel Process. Technol. 85, 2004, pp. 933 945.

[11] B. Pürevsüren, Ya. Davaajav, R. Erdenechimeg, Investigation on largest coal deposits in Mongolia, Monograph, Toonotprint, 2010.

[12] G. H. Taylor, M. Teichmuller, A. Davis, C. F. Diessel, R. Littke, and P. Robert, Organic Petrology, Gebr.Borntraeger Stuttgart, 1998, p. 704.

[13] S. Batbilig, B. Purevsuren, Ya. Davaajav, J. Namkhainorov, Thermal processing of Khoot coal and characterization of obtained solid and liquid products. Mongolian Journal of Chemistry, 15 (41), 2014, pp. 66-72.

[14] J. Narangerel, Chemistry and Technology of coal, UB, 2011, p. 388.

[15] Ts. Tsedevsuren et al. Hydrogenation of Bayanteeg coal of Mongolia, Chemistry of Solid Fuels (Russian Academy of Sciences), 6, 1981, p.17. 